\title{
A Model of Financial Shocks at Bank and Interbank of Iran (DSGE)
}

\author{
Shakeri, Abbas* \\ Ahmadian, Azam ${ }^{* *}$
}

Received: 7/7/2014 Approved: 12/14/2014

\begin{abstract}
This paper proposes a fully micro-founded framework that incorporates optimizing banks into a DSGE model, and evaluates the role of banks and financial shocks in the Iranian business cycles. We consider banks that offer different banking services and interact in an interbank market. Loans are produced using interbank borrowing and deposits. Banks have monopoly power, but cannot set nominal deposit and prime lending rates. The model also includes financial and unconventional monetary policy shocks. The main findings are: (1) Capturing the key features of the economy of Iran; (2) bank behavior substantially affects credit supply conditions and the transmission of different shocks; (3) financial shocks have significant effects on the Iranian business cycle fluctuations.
\end{abstract}

Key words: Banks, Interbank market, Financial shocks, Monetary policy JEL Classification: E12, E32, E37, E44, G21, G33

\footnotetext{
* Professor, Faculty of Economics, Allame TabaTabaee University, Iran

${ }^{* *}$ Researcher, Monetary and Banking Research Institute, Iran.

E-mail: azam_ahmadyan@yahoo.com
} 


\section{Introduction}

The ongoing global financial crisis underscores the need to develop DSGE models with real financial linkages and an active banking sector. Such a model would allow an empirical evaluation of banks' role and behavior in the transmission and propagation of supply and demand shocks, and an assessment of the importance of financial shocks as a source of business cycles. The banking sector, however, has been ignored in most DSGE models used for policy purposes. Moreover, in the literature, financial frictions are usually modeled on the demand side of the credit market using either the Bernanke, Gertler and Gilchrist (1999) financial accelerator mechanism (BGG, hereafter) or the Lacovello (2005) framework. In light of the ongoing financial crisis, real financial linkages have become the focus of attention.

This paper proposes a micro founded framework that incorporates an active banking sector and a credit market into a DSGE model with a financial accelerator a la BGG (1999). The model is calibrated to the economy of Iran and is used to evaluate the role of profit-maximizing banks in business cycles and in the transmission and propagation of shocks to the real economy, to assess the importance of financial shocks in explaining macroeconomic fluctuations, and to examine the potential role of unconventional monetary policies (quantitative and qualitative monetary easing) in offsetting the real impacts of the financial crisis.

The paper is related to the following studies: Lacoviello (2005, 2011), Gerali et al. (2010), Smits and Wouters (2007), Dib (2012) De Walque (2010) and Giri (2014). Our basic model is based on BGG (1999). The key additions to this model are the supply side of the credit market and an active banking sector.

This paper explains two phenomena. First, banks confront with various risks because they play an important role in financing. These risks include 
the risk of mismatch between assets and liabilities which leads to shortage of liquidity and liquidity risk. When banks confront with liquidity shortage they can borrow from the central bank through the credit lines or other banks that have excess fund. Borrowing from the central bank has inflationary effects while the transfer of surplus funds from institutions with excess liquidity to institutions with liquidity shortage will have not an inflationary effect. Banks also have credit risks, because firms default on their borrowings from banks.

Interbank market is one component of money market where banks and other credit institutions engage in transactions with each other for short-term financing. This market plays two vital roles in new financial systems. The first and most important role is the central bank leading to intervene actively and effectively in the implementation of monetary policy through interest rates. Second, efficient interbank markets, transfer liquidity from financial institutions with surplus funds to institutions with deficit funds.

This paper assumes defaults on banking credit and interbank borrowing. Because of relationship with the banks in interbank market and the real economy, a bank can also transfer any kind of risk to other banks and to the real sector. If borrowing from the interbank market, which is a type of shortterm financing, is defaulted, it will reduce the bank's credit rating and its credit strength.

Therefore, in this article, the default of banking credit and interbank borrowings is designed in the context of a dynamic stochastic general equilibrium model to study and analyze the real effects. The overall structure of the paper is as follows. Section 2 presents methodology. Section 3 gives literature review. Section 4 presents the model. The parameter estimation is represented in section 5. Section 6 presents Impulse-response Function. Conclusion is described in section 7. 


\section{Methodology}

\subsection{Banks and Interbank Markets}

Banks are a particular type of economic entity, characterized by the provision of maturity transformation to other agents within the economy. This brings with it a particular kind of risk to which any bank is necessarily exposed. This risk consists of the different maturity profiles of the assets and liabilities in its portfolio, since it is usually not possible to match any sudden outflows from deposits with inflows from a portfolio of loans.

The management of this phenomenon is a major part of a bank's business. In order to meet expected withdrawals, some proportion of total deposits is kept in the form of reserves (for example as deposits with the central bank) and a stock of liquid short term assets is generally kept on the balance sheet. Since reserves generally earn a much lower return than funds invested in other financial assets or loans, there exists a trade-off between safety and profitability.

Reserves are also used by banks to settle transactions between each other as part of normal business. When a depositor of one bank withdraws funds and uses them in a transaction, a different individual will ultimately deposit them at a (potentially) different bank. This requires a transfer of reserve funds from one bank to another. This type of transfer, of which millions occur on any given day, will affect the reserve holdings of individual banks, but would not affect the aggregate stock of reserves. Apart from transactions between the treasury and the central bank, there are only two forces which may change this aggregate. The first is obvious: if the depositor withdrew the funds and held them in the form of cash without depositing them, there would be a debit from his banks' reserve account, but no credit to any other bank. The total stock would thus have decreased. Of course, the converse process also occurs on a daily basis.

However, the total stock of reserves does not generally change a great deal, since the popular requirement for physical cash is relatively stable. The 
other force which may change reserve holding, namely the central bank itself, may be more important in that sense. Modern central banks have three different means of injecting or withdrawing reserves from the system. By far the most commonly used are their open market operations, which are in effect auctions aimed at buying or selling reserve funds in order to change the aggregate.

When a bank finds itself in the difficult position of facing liquidity shock large enough to prompt an immediate requirement for additional reserves, it may also access discount lending facilities. Since these programs charge interest rate some margin above policy rates and need for their signals, some failure in liquidity management occur, these emergency facilities are used more rarely.

It should be noted then that the interbank market in which banks trade reserve funds do not affect the aggregate stock of reserves. Instead, they can only serve to help banks in their individual reserve management. This implies that there are two sides to any trade in this market. On one hand, those banks which believe that their depositor's liquidity needs will be low for a given period, may choose to reduce their holding of reserves without fully committing to lending the funds as illiquid loans into the real economy. On the other, should a bank's estimation turn out to be incorrect, the difference can be made up quickly within the market by borrowing or lending funds and thus balancing the books. Interbank markets are then credit markets, in structure somewhat similar to any other market. Although they are of particular importance to the functioning of the monetary system, in principle lending banks face credit risks not dissimilar to those they face when lending to other types of agents in the economy. Although such risks were previously considered to be very low, the financial crisis of 2007/2008 highlighted that their management can be critical to the funding strategy and indeed the survival of a large financial institution [Weltewitz (2009)]. 


\subsection{Recent Theoretical Developments in the Analysis of Interbank Term Structures}

Perhaps the closest paper in relation with this paper is developed by Heider, Hoerova \& Holthausen (2009), who present a model of an interbank market under adverse selection. In keeping with much of the modeling of banks, some proportion of the market in their model suffers a liquidity shock as impatient consumers withdraw their endowments. Banks must decide whether to invest those endowments in a liquid short-term or asset or a risky, illiquid long term alternative. When they face withdrawals, they must then choose whether to liquidate some of their long-term assets or keep them until maturity and instead secure funding for the meantime from other banks. Due to the difference in riskiness between long-term assets (the precise knowledge of which is private), some banks will be willing to lend, while others become borrowers.

Since those banks with a safer asset are assumed to be able to liquidate it at a lower cost, they will be the first ones to do so if the interbank interest rate increases beyond a critical value. This gives rise to an adverse selection problem. The authors derive a risk premium, which increases unequivocally as adverse selection becomes a bigger problem, which occurs when the expected riskiness of long-term assets increases. Indeed, the authors show that it is possible that the interbank market breaks down entirely, given sufficiently risky assets.

Although this analysis is close in spirit to the one proposed here, its approach is fundamentally different. In Heider et al.'s (2009) paper, interbank markets are defined to have only one maturity. By using the methodology of game theory, it is proposed in this thesis that asymmetric information and perceived increased riskiness does in fact have an impact across the entire term structure of contracts traded between banks.

One of the more recent applications of screening methods is presented by Acharya \& Viswanathan (2008), who introduce asset pricing in their bidimensional loan contract model in which firms pledge collateral to 
counteract a moral hazard situation in a credit market. Since the authors introduce a delay in asset liquidation when firms fail to repay loans, liquidity shocks can have a contagion effect in their model. As in Bester (1987), credit rationing would occur in a pooling equilibrium and as a result, pledging cash collateral is an optimal strategy, requiring sales of assets by the borrower. By modeling a market for asset sales, the authors establish that by posting collateral, not only is rationing weakened, but asset prices are actually more stable than what would have been the case otherwise. The relationship between asset pricing and credit markets is obviously a direct link with the proposed research.

Another model of immediate significance to the research question is presented in Freixas \& Jorge (2008), which focuses on modeling interbank markets. In particular, it makes use of a screening game to explain why a lending channel of monetary transmission may exist. As such, it is a model of the interbank market at the core of the broader term structure. In their model, Freixas \& Jorge demonstrate a situation in which banks in interbank markets can be rationed, and thus are unable to provide funds to positive NPV projects in the real economy. The authors produce this result by referring to a chance that banks suffering large liquidity shocks may borrow in order to finance a private benefits project. In the ensuing screening game (in which contracts are defined in terms of an interest rate and loan size), borrowing banks that are undertaking this gamble want to maximize the loan they take out. Indeed it is shown that there exists a loan size above which only such bad banks would be attracted and lenders would thus have an incentive to decrease the size, resulting in Type I credit rationing.

\section{Literature Review}

After the banking crisis in 2007, the importance of relationship of banking sector with the real sector was more than ever before. Therefore, modeling 
the transmission of shocks from the banking sector to the real sector was entered into the DSGE models. In the literature on closed economy models, the two main ways in which an active banking system is incorporated into DSGE models with financial friction, is through the external finance premium proposed in Bernanke, Gertler and Gilchrist (BGG, 1999) or through Collateral constraint tied to real estate values for entrepreneurs proposed in Lacoviello (2005). Gerali and et al. (2010), Smits and Wouters (2007) designed DSGE models based on the framework of the banking sector, households and firms. While the banking sector and financial intermediaries receive deposits from households and supply credit to firms, Lacoviello (2011) introduces a banking sector with one bank and focuses on how financial shocks (repayment shocks) affect an economy with patient and impatient households. This group of studies has not addressed the role of the interbank market at the balance sheet shocks transmitted to the real economy. But the effect of shocks as banks default shocks on the real sector has been discussed. The results represent reduced credit supply and thus, reduced economic growth.

Another group of studies have entered interbank issue at DSGE model. Giri (2014) has considered two types of banks. Banks facing with liquidity shortage for credit supply and thus borrow from the interbank market and give credit to the real sector; the second group of banks that have excess funds, lend to interbank and invest in less risky assets such as bonds. Results suggest that credit shocks in the interbank market, has reduced the supply of loans from the banking sector to the real sector of the economy, and then, has reduced investment and economic growth. On another hand, the credit shock in the interbank market raises the interest rates of credit at the interbank market.

While modeling the interbank market, Dib (2010) has assumed that banks are related together through the interbank market. Banks are financed through borrowing from the interbank and capital market. Banks have monopoly power to set interest rates on deposits and loans. Combined 
portfolio and leverage ratios are determined exclusively. They may default the borrowings from other banks. In addition, shocks starting from the banking system are also investigated as monetary policy shocks. The main findings of the paper show that default at the interbank market reduces the bank's capital and has a negative effect on production. Deposits and borrowings from the interbank market affect the supply of credit and production. Increased default of borrowing from other banks in the interbank market will increase inflation and policy interest rate.

De Walque et al. (2010) have considered interbank market and regulatory sectors in DSGE. This model has considered the interaction between the banking system and the real sector of the economy and the importance of stabilizing the financial sector and regulatory policy. In this model, three assumptions have been made. First, firms face default regarding to banks. Second, banks in the interbank market confront with nonperforming loans. Third, lack of liquidity at interbank is compensated with liquidity injection from the central bank. Results indicate that nonperforming at firms causes nonperforming at interbank, then reduces the credit supply and growth but increases inflation. NPLs appear with a lag of several years from decreasing of growth rate.

\section{The Relationship between the Banking System and Business Cycle in Iran}

To understand the relationship between the variables of the banking sector and business cycle, we analyze the amount and direction of correlations between bank variables, including deposits, credit facilities, the NPL and business cycle. We use HP filter to extract cyclical components of these variables.

Variables of banks such as deposit and loans change direction with the business cycle, as the boom have ascended and descended during the 
recession. This situation, confirms the correlation coefficient that shows the magnitude of correlation between variables and GDP volatility. Correlation between domestic production and deposit is 0.33 and correlation between domestic production and loan is 0.51 , which indicate that there is a positive correlation between GDP and banking variables. Loans are more volatile than GDP but deposit swings.

\section{Figure 1: Cycle component of deposit, loan and GDP}

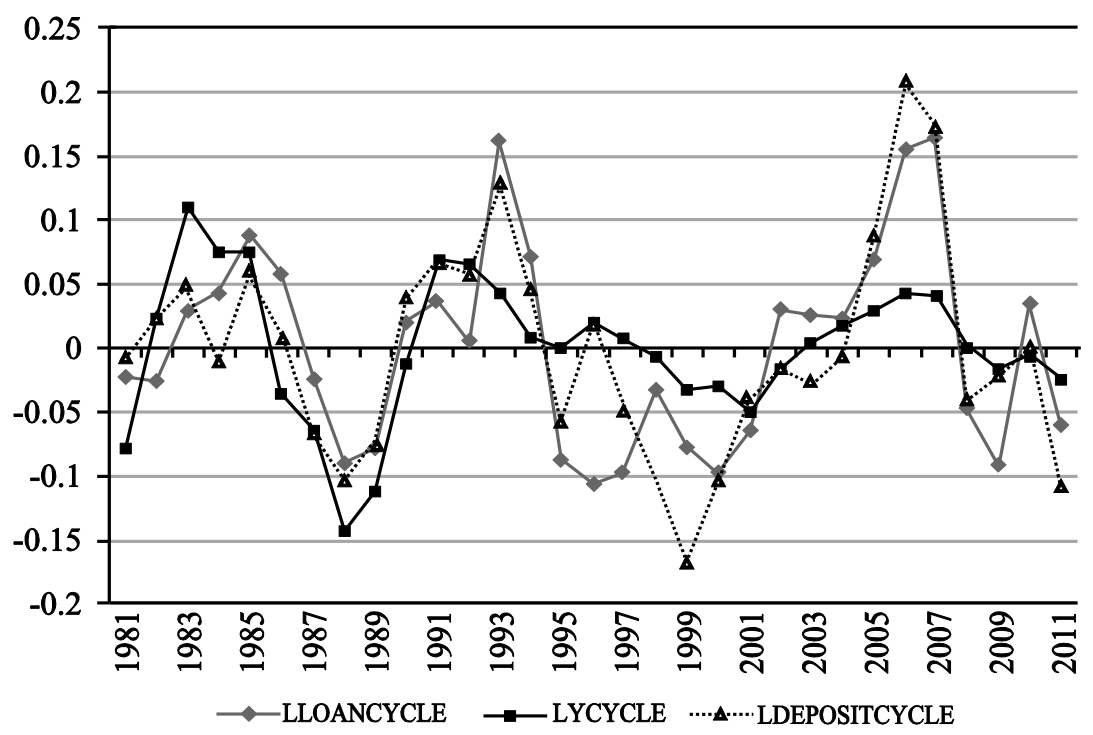

Figure 2 shows NPL and GDP move in opposite directions. Even in the boom period, NPL dropped and in the recession increased. So GDP and NPL have a negative correlation. 
Figure 2: Cycle component of GDP and NPL

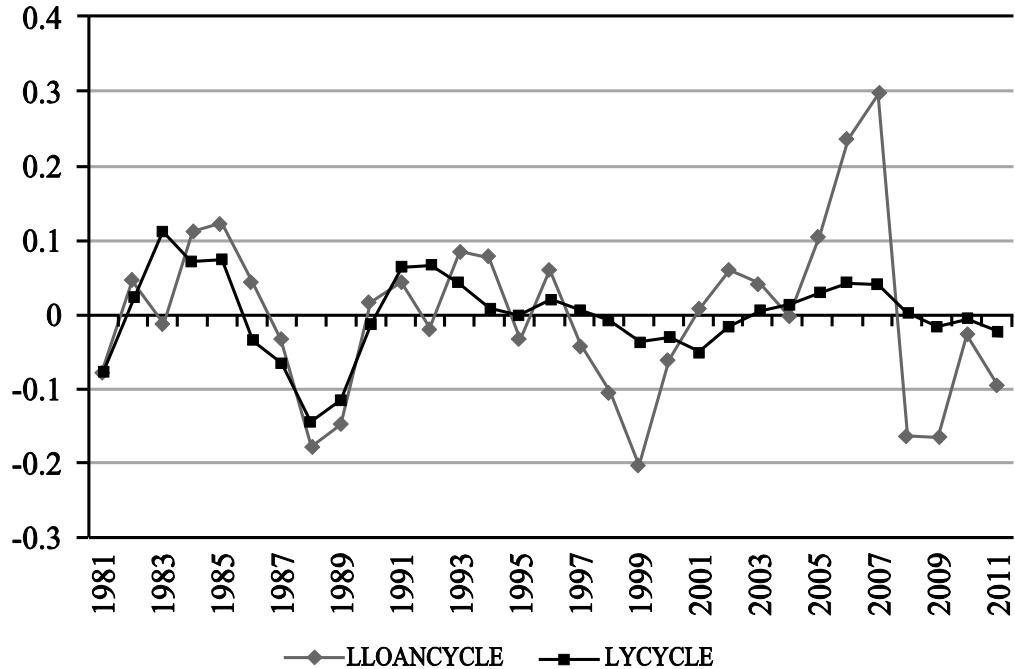

Figure 3: Growth of GDP, growth of manufacturing sector and NPL to loan

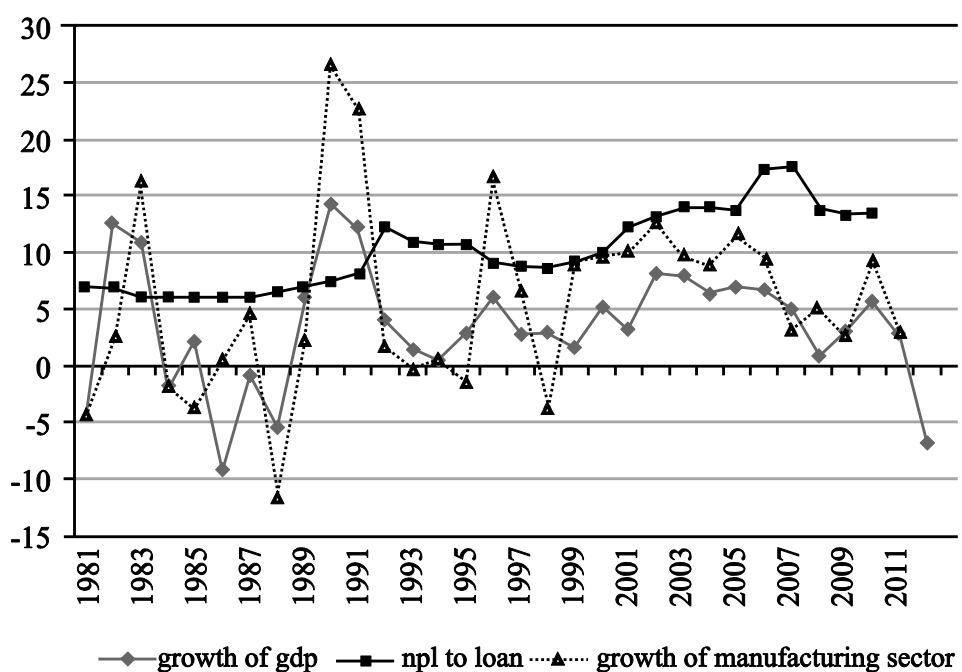


As Figure 3 shows, when economic growth and the growth of industrial sector was negative, NPL to total loans increased after two lags. For example, in 1986, 1988 and 1998 when the growth of the manufacturing sector was negative, economic growth has been negative. NPL to total loans has positive growth in the years 1991 and 1992. The economic slowdown and reduced growth of the manufacturing sector reduce manufacturing sector's ability to repay loans from the banking network.

As in Figure 4, it is observed that deposit and facilities of banks have similar fluctuation. In other words, increase of bank liabilities increases lending power. But economic growth follows the behavior of liabilities, with a lag period. With reduced resources, and consequently the cost of the bank in each period, economic growth is decreased in the postwar period. For example, despite the reduction in growth of deposits and funds starting in 1996, the economic slowdown started in 1996.

Figure 4: Growth of facility, deposit and GDP

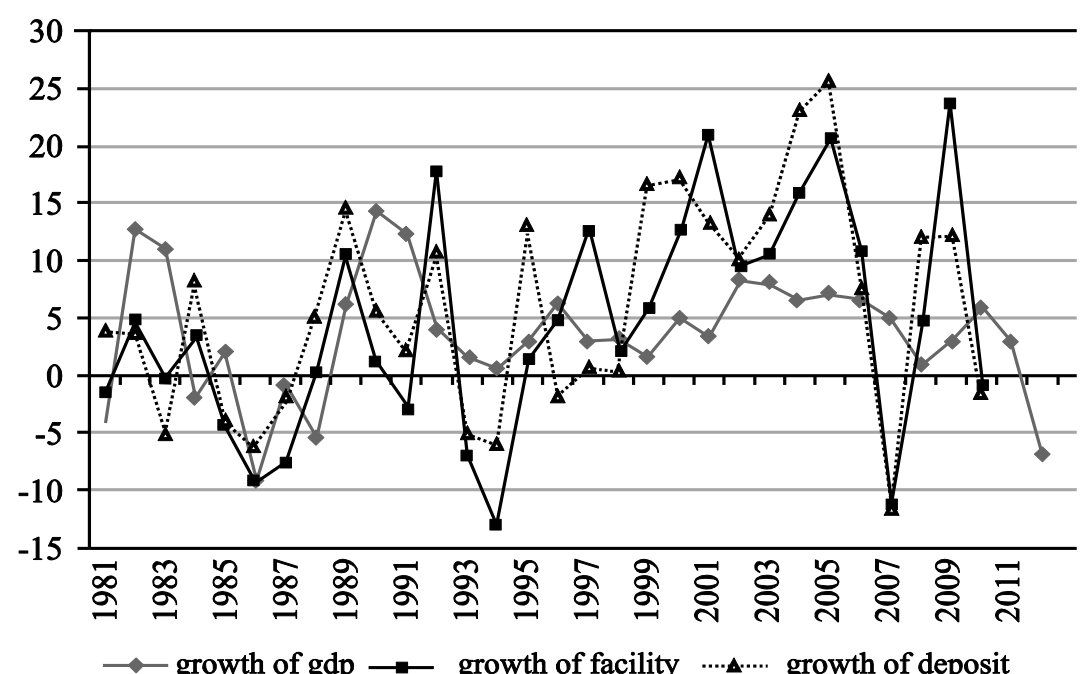

Note: Economic growth is specified at right axis and deposit and facilities on the left axis. 


\section{Structure of the Model}

As pointed out by Giri (2014), we assume banking sector confronts with shortage of liquidity and borrows from interbank. Like De Walque et al. (2010), it is assumed that banks borrow from interbank, but they don't pay off on time. We suppose nonperforming loan at interbank, because in recent years some banks have not reimbursed their borrowing from interbank on time. Furthermore, interbank market can confront with risk of non-repay fund and due to the significant role of the banking system in financial markets; it will have deleterious effects on macroeconomic variables such as output and inflation.

\subsection{Households}

Households have constraints and decide the amount of consumption, the amount of labor they wish to supply to the production sector and the amount of liquidity according to the following utility function:

$$
\sum_{s=0}^{\infty}\left(\beta^{h}\right)^{s} E_{t}\left[\frac{\left(c_{t}\right)^{1-\sigma_{c}}}{1-\sigma_{c}}-\frac{N_{t}^{1+\sigma_{n}}{ }_{t}}{1+\sigma_{n}}+\frac{1}{1-\vartheta}\left(\frac{M_{t}^{h}}{P_{t}}\right)^{1-\vartheta}\right]
$$

Where $\beta$ is the inter-temporal discount factor, $c_{t}$ denotes real consumption, $N_{t}$ is supply of labor in goods sector, $M_{t}^{h}$ is the liquidity at households. $\sigma_{c}$ denotes inverse of the elasticity of inter-temporal substitution of consumption, $\sigma_{l}$ is inverse of elasticity of inter-temporal substitution of labor, and $\vartheta$ is elasticity of liquidity of household. They are subject to the budget constraint:

$$
m_{t}^{h}+c_{t}+d_{t}+i_{t}=w_{t} N_{t}+\left(1+r_{t-1}^{d}\right) \frac{d_{t-1}}{\pi_{t}}+r_{t}^{k} k_{t}+\frac{m^{h}{ }_{t-1}}{\pi_{t}}+t_{t}+\frac{\pi_{t}^{f}}{p_{t}}+\frac{\pi_{t}^{b}}{p_{t}}
$$


Where $w_{t}$ is the real wage, $\mathbf{t}_{\mathrm{t}}$ is tax, $1+\mathrm{r}_{\mathrm{t}}^{\mathrm{d}}$ is the interest rate that households receive from bank, $D_{t}=\int{ }_{0}^{1} D_{j t} d_{t}$ is the deposit, $\pi_{t}^{f}$ is profit of production sector and $\pi_{\mathrm{t}}^{\mathrm{b}}$ is banking profit, $\pi_{t}$ is inflation, $\mathrm{k}_{\mathrm{t}}$ is quantity of capital, and $i_{t}$ is investment. Investment is added to capital stock at the beginning of the period and creates future capital stock. $\mathrm{k}_{\mathrm{t}+1}$ is obtained:

$k_{t+1}=(1-\delta) k_{t}+i_{t}$

Where $\delta$ is depreciation rate. Let's obtain first order conditions with respect to $c_{t}, N_{t}, d_{t}, m_{t}^{h}, k_{t}$.

\subsection{Final Good Producer}

Final good producer buys intermediate goods that are shown with $\mathrm{j}$, and produces final goods by using Dxit- Stieglitz.

$$
Y_{t}=\left(\int_{0}^{1} Y_{j t}^{\left(\frac{\theta-1}{\theta}\right)} d_{j}\right)^{\frac{\theta}{\theta-1}} \quad \theta \succ 1
$$

Where $Y_{j t}$ is intermediate goods, $\theta$ is constant elasticity of substitution between intermediate goods. Final good producers try to determine their purchases of intermediate goods according to different prices to obtain maximum profit. Demand function for each product by any intermediate producer can be obtained:

$Y_{j t}=\left(\frac{P_{j t}}{P_{t}}\right)^{-\theta} Y_{t}$

Price for final goods is: 


$$
P_{t}=\left(\int_{0}^{1} P_{j t}^{1-\theta} d_{j}\right)^{\frac{1}{1-\theta}}
$$

\subsection{Intermediate Producer}

Production sector, characterized by monopolistic competition and Rotenberg pricing, adopts a standard Cobb-Douglas production function with capital $k_{t}$, and labor $N_{t}$ subject to productivity shocks.

$$
Y_{j t}=A_{t} N_{j t}^{1-\alpha} K_{j t}^{\alpha}
$$

Where $\alpha \in(0,1)$ is elasticity of production with respect to capital.

$$
A_{t}=\rho_{A} A_{t-1}+\left(1-\rho_{A}\right) \bar{A}+\varepsilon_{A, t} \quad \varepsilon_{t, A} \approx N\left(0, \sigma_{\varepsilon_{t, A}}\right) \rho_{g} \in(0,1)
$$

$A_{t}$ is technology shock. At the beginning of every period, each firm $\mathrm{j}$ receives $l_{j t}$ from the bank and is financing $\gamma_{t}$ proportion with cost of capital stock and labor. $\gamma_{t}$ is:

$\gamma_{t}=\left(1-\rho_{\gamma}\right) \bar{\gamma}+\rho_{\gamma} \gamma_{t-1}+\varepsilon_{\gamma, t} \quad \varepsilon_{t, \gamma} \approx N\left(0, \sigma_{\varepsilon_{t, \gamma}}\right) \quad \rho_{\gamma} \in(0,1)$

$l_{j t}$ is:

$$
L_{j t}=\gamma_{t}\left(P_{j t} r_{t}^{k} K_{j t}+P_{j t} W_{t} N_{j t}\right)
$$

They pay $r_{j t}^{l}$ which is the interest rate of loan. Adjustment cost confronted by firms is: 


$$
P A C_{t}^{j}=\frac{\varphi_{f}}{2}\left(\frac{P_{j t}}{(\bar{\pi}) P_{j t-1}}-1\right)^{2} Y_{t}
$$

Where $\varphi_{f} \geq 0$ is adjusted cost parameter, $1+\pi_{t}$ is inflation rate, $Y_{t}$ is total production. The marginal cost is:

$$
m c_{j t}=\frac{\left[\gamma_{t}\left(1+r_{t}^{l}\right) w_{t}\right]^{1-\alpha}\left(\gamma_{t}\left(1+r_{t}^{l}\right) r_{t}^{k}\right)^{\alpha}}{\alpha^{\alpha}(1-\alpha)^{1-\alpha} A_{t}}
$$

Firms wish to maximize profit:

$$
\pi_{j t}^{f}=P_{j t} Y_{j t}-P_{t} m c_{t} Y_{j t}-P A C_{t}^{j}
$$

Then obtain first order conditions with respect to, $k_{j t}, N_{j t}$ and $P_{j t}$.

\subsection{Commercial Banks}

This paper models banks by introducing monopolistic competition, but interest rates of deposit and loan are determined by the central bank. They intermediate all the transactions among agents. They collect deposit $D_{j t}$ from household and set deposit rate $r_{t}^{d}$ as a markdown below the loan rate $r_{t}^{l}$. They also make claims against firms and receive $r_{t}^{l}$. In each period, firms are faced with nonperforming loan rate $\alpha_{t}^{b}$ and banks receive $\left(1-\alpha_{t}^{b}\right) r_{t}^{l}$.

$\alpha_{t}^{b}=\rho_{\alpha b} \alpha_{t-1}^{b}+\left(1-\rho_{\alpha b}\right) \bar{\alpha}+\varepsilon_{t, \alpha b} \quad \varepsilon_{t, \alpha b} \approx N\left(0, \sigma_{\alpha b}\right)$

$\alpha_{t}^{b}$ is nonperforming loan shock.

If the bank is faced with a shortage of funds, it borrows from the interbank market $D_{t}^{i}$ and pays $r_{t}^{i}$. Banks set interest rate of interbank by 
mutual agreement. $r_{t}^{i}$ must be less than $r_{t}^{l}$ and more than $r_{t}^{d}$. If $r_{t}^{i}$ is more than $r_{t}^{l}$, they don't want to extend loans to firms, because claim to interbank is riskless and has high yield. Banks need a certain amount of borrowing from interbank and deviation from steady state equilibrium condition brings quadratic cost: $\frac{1}{2} \varphi d i\left(\frac{D_{t}^{i}}{\bar{D}}-1\right)^{2}$

Where $\varphi d i$ is quadratic cost parameter. $\gamma_{t}^{i}$ is non-repayment ratio of due to interbank. If banks cannot repay timely, they are confronted with cost: $\frac{1}{2} \varphi \gamma d i\left[\gamma_{t}^{i} d_{t}^{i}\right]^{2}$

$\gamma_{t}^{i}=\rho_{\gamma} \gamma_{t-1}^{i}+\left(1-\rho_{\gamma}\right) \bar{\gamma}+\varepsilon_{t, \gamma} \quad \varepsilon_{t, \alpha b} \approx N\left(0, \sigma_{\alpha b}\right)$

where the above equation shows the non-repayment ratio of due to interbank shock.

Due to interbank is:

$d_{t}^{i}=\left(d_{t-1}^{i}\right)^{\phi_{d i}^{d i}}\left(y_{t}\right)^{\phi_{d i}^{y}} \varepsilon_{t, d i}$

$\kappa K_{t} \alpha_{t}^{b}$, represents what the bank earns in the case of default, that under limited liability, the effective value of collateral pledged by borrower is $\kappa K_{t}$. Raw collateral consists therefore of the physical assets of the firm and $\kappa$ measures the degree of credit market imperfections.

Accordingly, profit of banks is:

$$
\begin{aligned}
& \pi_{t}^{b}=\left(1-\alpha_{t}^{b}\right)\left(1+r_{t}^{l}\right) L_{t}+\kappa K_{t} \alpha_{t}^{b}-\left(1+r_{t}^{d}\right) D_{t}-\left(1+r_{t}^{i}\right) \gamma_{t}^{i} D_{t}^{i} \\
& -\frac{1}{2} \varphi_{d i \gamma}\left[\left(1-\gamma_{t}^{i}\right) D_{t}^{i}\right]^{2}-\frac{1}{2} \varphi_{d i}\left[\frac{D_{t}^{i}}{\bar{D}_{i}}-1\right]^{2}
\end{aligned}
$$

Balance sheet of banks is: 
$l_{t}=d_{t}^{i}+\left(1-\eta_{t}\right) d_{t}$

Where $\eta_{t}$ is reserve requirement.

Banks maximize profit subject to $d_{t}^{\prime}, I_{t}, d_{t}$.

\subsection{Central Bank}

Central bank is able to set loan interest rate and reserve requirement. Loan Interest rate is:

$$
\left(1+r_{t}^{l}\right)=\left(\frac{1+r_{t-1}^{l}}{1+\bar{r}^{l}}\right)^{\rho_{r}}\left(\frac{1+\pi_{t}}{1+\bar{\pi}}\right)^{\rho_{\pi}}\left(\frac{y_{t}}{\bar{y}}\right)^{\rho_{y}}\left(\frac{\mu_{t}}{\bar{\mu}}\right)^{\rho_{m}}+\varepsilon_{l, t}
$$

Where $\rho_{\mathrm{y}}, \rho_{\pi}, \rho_{\mathrm{m}}, \rho_{\mathrm{r}}$ are the weights assigned to the output, inflation stabilization, growth of money and interest rate of previous period. Growth of money is:

$\mu_{t}=\frac{M_{t}}{M_{t-1}}\left(\pi_{t}\right)$

Reserve requirement is:

$\eta_{t}=\pi_{t}^{\phi_{\eta}^{\pi}} \eta_{t-1}^{\phi_{\eta}^{\eta}} \varepsilon_{t, \eta}$

$\phi_{\eta}^{\pi}, \phi_{\eta}^{\eta}$ are weights assigned to inflation rate and reserve requirement at previous periods.

\subsection{Government and Oil Sector}

Government is financed with tax $t_{t}$, oil revenue or ${ }_{t}$ and money $\mathrm{m}_{\mathrm{t}}$. Government expenditure is: 


$$
g_{t}=t_{t}+o r_{t}+m_{t}-\frac{m_{t-1}}{\pi_{t}}
$$

Tax is:

$$
t_{t}=y_{t}^{\varphi_{t}^{y}}
$$

Where is weight of output. Oil revenue shock is:

$$
\begin{aligned}
& \text { or }_{\mathrm{t}}=\rho_{\mathrm{or}} \text { or } \\
& \mathrm{t}-1+\left(1-\rho_{\mathrm{or}}\right) \text { or } \\
& \bar{r} \text { is oil revenue at steady state. }
\end{aligned}
$$

\subsection{Market Clearing}

In equilibrium, the output and liquidity market must clear:

$$
\begin{aligned}
& y_{t}=c_{t}+i_{t}+g_{t}+A C_{t} \\
& m_{t}=m_{t}^{h}+d_{t}
\end{aligned}
$$

\section{Estimation}

\subsection{Methodology and Stylized Facts}

This paper uses Bayesian techniques to estimate the structural parameters of the model. First, we obtain the first order condition and linearize them, which are explained in Appendix A and B. Then we solve the model. We use the Kalman filter to drive the likelihood function and find the expression of $\log$ posterior Kernal. Second, for given parameter values and the given sample data, we maximize the log posterior Kernal, we used Monte Carlo method such as Metropolis - Hastings algorithm to obtain the posterior distribution. The posterior means of the parameters are then used to draw statistical inference on the parameters. The Sample runs during 1981-2012. 


\subsection{Calibrated Parameters}

We fix some parameters, because they are either notoriously difficult to estimate or because they are better identified using other information. Adjusted cost of capital, adjusted cost of inflation, quadratic cost parameter of due to interbank and cost of non-repayment are in line with the literature [Wooters (2007), Dib (2010), De Walque (2010)]. Adjusted cost of capital $\varphi_{\mathrm{k}}$ is 8.6., adjusted cost of inflation $\varphi_{\pi}$ is 4.26. Quadratic cost parameter of due to interbank $\varphi d i$ and cost of non-repayment $\varphi \operatorname{di} \gamma$ are 0.001 and 679. Some parameters are calibrated appropriately for the economy of Iran e.g. $\phi_{\mathrm{di}}^{\mathrm{di}}$ and $\phi_{\mathrm{di}}^{\mathrm{y}}$ are 0.46 and 0.347 .

We compare means, standard deviation and auto correlation to assess the model. Table 1 shows moments and table 2 shows auto correlation for some variables. They show that, the model simulates economy of Iran appropriately.

\section{Table 1: Moments}

\begin{tabular}{|c|c|c|c|c|}
\hline \multicolumn{3}{|c|}{$\begin{array}{c}\text { Standard } \\
\text { deviation }\end{array}$} & \multicolumn{2}{c|}{ mean } \\
\cline { 1 - 3 } real & model & real & model & \\
\hline 1.99 & 2.041 & 255027.13 & 254932.02 & Gross domestic product \\
\hline 2.12 & 2.15 & 17.5321 & 17.5328 & Inflation \\
\hline 1.64 & 1.56 & 16781.19 & 16797.98 & Loan \\
\hline 1.52 & 1.54 & 1602.74 & 1603.26 & Deposit \\
\hline
\end{tabular}

We use Eviews software to calculate autocorrelation for real variables, and then compare them with simulated model. Results show the real and simulated models are similar and this model is appropriate for the economy of Iran (see Table 2). 


\section{Table 2: Auto-correlation, real and simulated}

\begin{tabular}{|c|c|c|c|c|}
\hline \multicolumn{2}{|c|}{$\begin{array}{c}\text { Simulated auto- } \\
\text { correlation }\end{array}$} & \multicolumn{2}{c|}{ Real auto-correlation } & \multirow{2}{*}{} \\
\hline Second lag & First lag & Second lag & First lag & \\
\hline 0.61 & 0.81 & 0.79 & 0.89 & $\begin{array}{c}\text { Gross domestic } \\
\text { product }\end{array}$ \\
\hline 0.37 & 0.07 & 0.42 & 0.08 & inflation \\
\hline 0.72 & 0.78 & 0.72 & 0.87 & loan \\
\hline 0.73 & 0.78 & 0.75 & 0.89 & deposit \\
\hline
\end{tabular}

\subsection{Prior and Posterior Estimates}

Prior and Posterior Estimates are reported in Table 3. The method used to obtain the initial values of the parameters includes some parameters such as discount rate and depreciation rate that are identified by solving the model. The weights assigned to the output, inflation stabilization, growth of money and interest rate of previous period, weights assigned to inflation rate and reserve requirement at previous periods and weights of output are estimated by Eviews according to their functions. Parameters of shocks are also estimated by Eviews software according to the following equation:

$\log \left(X_{t}\right)=c+\rho \log \left(X_{t-1}\right)+\varepsilon_{x_{t}}$

Where $\rho$ is Autoregressive Coefficient and its standard deviation of $\varepsilon_{x_{t}}$ is used as a standard deviation of variable. Productivity shock is selected according to the structure of the model. Distribution of parameters is selected based on the characteristics of parameters and features of the distribution. 


\section{Table 3: Prior and Posterior}

\begin{tabular}{|c|c|c|c|c|c|}
\hline \multirow[t]{2}{*}{ Parameters } & \multicolumn{2}{|c|}{ Prior distribution } & \multirow{2}{*}{ Calibrated from } & \multicolumn{2}{|c|}{ Posterior distribution } \\
\hline & Mean & deviation & & mean & deviation \\
\hline$\sigma_{c}$ & 0.93 & 0.01 & Author's calculations & 0.9378 & 0.1 \\
\hline$\sigma_{n}$ & 0.63 & 0.01 & Author's calculations & 0.6394 & 0.05 \\
\hline$\vartheta$ & 0.67 & 0.01 & Author's calculations & 0.6697 & 0.01 \\
\hline$\delta$ & 0.24 & 0.01 & Solving model & 0.06 & 0.05 \\
\hline$\theta$ & 4.33 & 0.01 & Mark-up 30\% & 4.35 & 0.05 \\
\hline$\beta$ & 0.97 & 0.01 & Solving model & 0.9699 & 0.001 \\
\hline$\alpha$ & 0.78 & 0.01 & Author's calculations & 0.8167 & 0.05 \\
\hline$\rho_{A}$ & 0.53 & 0.01 & $\begin{array}{l}\text { appropriate structural } \\
\text { of model }\end{array}$ & 0.5038 & 0.05 \\
\hline$\rho_{\text {or }}$ & 0.56 & 0.01 & Author's calculations & 0.5524 & 0.05 \\
\hline$\rho_{p i}$ & 0.89 & 0.01 & Author's calculations & 0.6268 & 0.05 \\
\hline$\rho_{\text {mio }}$ & 0.82 & 0.01 & Author's calculations & 0.5606 & 0.05 \\
\hline$\rho_{y}$ & 0.36 & 0.01 & Author's calculations & 0.3626 & 0.03 \\
\hline$\rho_{\gamma^{i}}$ & 0.65 & 0.01 & Author's calculations & 0.63 & 0.05 \\
\hline$\phi_{\eta}^{\pi}$ & 0.062 & 0.01 & Author's calculations & 0.059 & 0.01 \\
\hline$\phi_{\eta}^{\eta}$ & 0.83 & 0.01 & Author's calculations & 0.83 & 0.001 \\
\hline$\kappa$ & 1.5 & 0.01 & $\begin{array}{c}\text { Collateral to loan } \\
\text { ratio }\end{array}$ & 2 & 0.1 \\
\hline
\end{tabular}

\section{Impulse Responses}

In this section we want to assess whether and how the transmission of shocks is affected by bank intermediaries in the context of the closed economy with 
interbank. We consider three shocks. The first is financial shock, and the second is monetary policy shock (demand shock). The third is technology shock (supply shock).

Figure 5: Non-performing loan shock

Interest rate of interbank
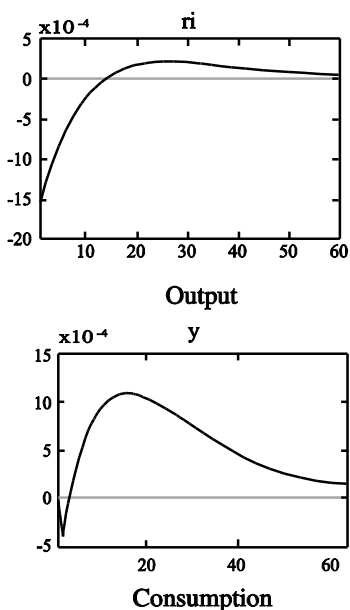

c

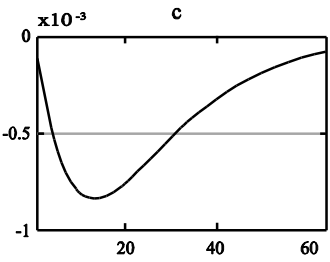

Deposit interest rate

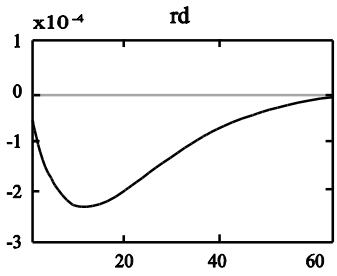

Due to interbank
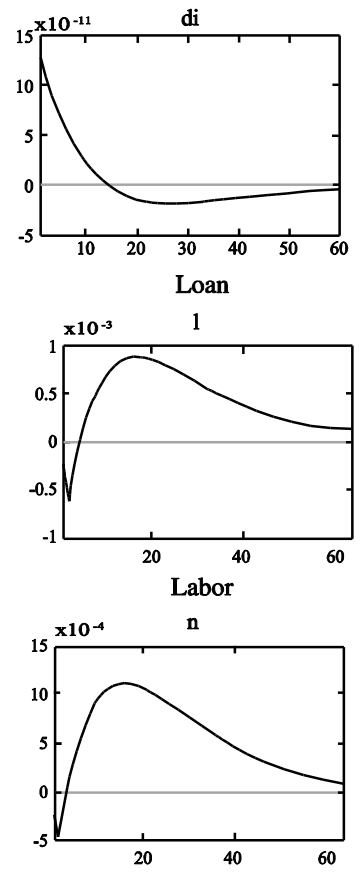

Capital stock

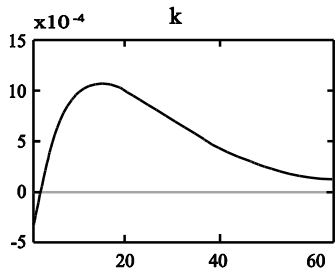

Loan interest rate
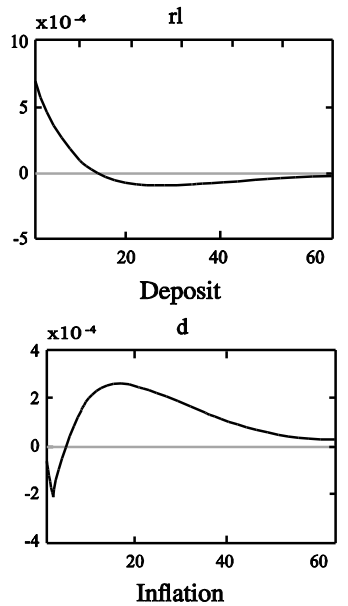

pi

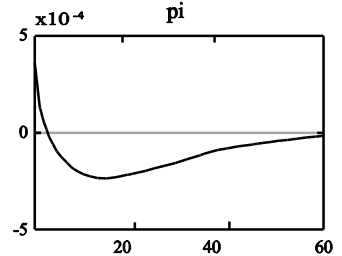

Investment

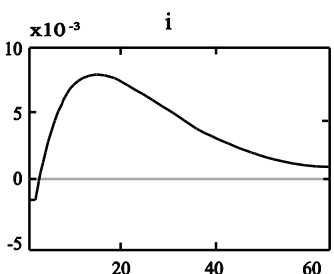




\subsection{Financial Shocks}

The introduction of the nonperforming loan (NPL) shock is to understand the effects of credit losses originating in production sector on business cycles. If sub primers pay back less than expected, bank suffers a loan loss and a reduction in bank capital. As a result, banks either raise new capital or reduce lending if raising new capital is difficult. Hence, the reduction in bank credit propagates recessions.

Figure 5 shows the impulse response of Iranian NPL shock on the economy of Iran. The consequences of the NPL shock on the domestic economy in this model are in line with Lacoviello (2011). NPL shock transmits to the economic activity through the following channels:

First, the NPL shock starts with the sub primers who pay banks less than what was initially agreed as their obligations, implying that savers transfer wealth toward the borrowers. When facing a positive shock to wealth, households consume more and withdraw deposit from banks. According to the balance sheet identity, decline in deposits leads to a large drop in loans to entrepreneurs. With the reduced loans, entrepreneurs have to accumulate less capital, so that aggregate output falls, then consumption falls.

Second, since the labor supply is elastic, the labor demand of households will also respond to the fall in output. The households save less because of the reduced savings, the marginal product of labor falls, then output declines. Inflation rises in response to the drop in output. The central bank reacts to the shock by raising the loan interest rate and banks reduce interbank interest rate. Due to falling at interbank interest rate, we see rising of borrowing from interbank. Third, the banking system puts direct pressure on the bank balance sheet by reducing the value of banks assets (loans) relative to liabilities (deposit). Without any further adjustment to either loans or deposits, banks borrow from interbank, hence, raise borrowing from interbank. Because of raising borrowing from interbank, interbank interest rate rises and falling of borrowing from interbank continues. The reduction 
of credit supply leads to a further decline in output, thus propagating the credit crunch (See Figure 5).

Figure 6 shows the impulse response of Iranian default shock in interbank on the economy of Iran. The consequences of this shock on the domestic economy in this model are in line with De Walque (2010). This shock is transmitted to the economic activity through the following channels.

\section{Figure 6: Default in interbank market shock}

Figure 6: Default in interbank market
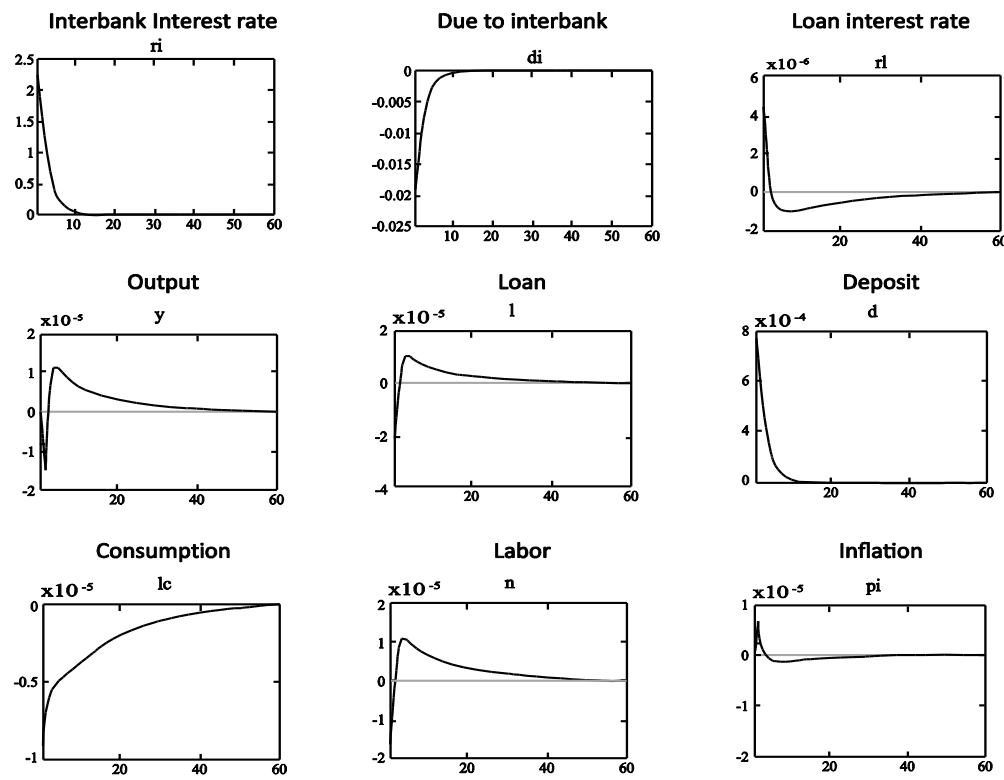

Deposit interest rate

Capital stock

Investment
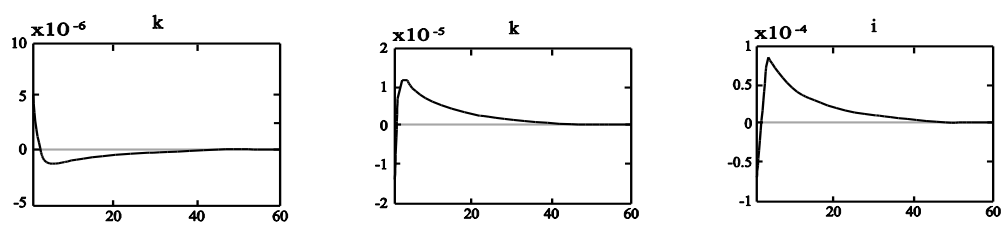
First, default shock at interbank starts with less than initially agreed payment of some banks. This phenomenon leads to fall of confidence between banks and banks cut deposit allocated to interbank lending. Banks with default cannot borrow from other banks and borrow from interbank. Due to default in interbank, interbank interest rate rises, then it raises interbank lending and borrowing.

Second, due to default shock at interbank and fall in interbank borrowing, bank funds and loan decrease. Hence, entrepreneurs borrow less and produce less. Output falls and Inflation declines in response to the drop in output. But deposit interest rate rises and households consume less and save more. Then deposit and loan rise in response to the rising in interest rate. This phenomenon leads to rise of capital stock, investment and output, but fall of inflation.

\subsection{Monetary policy shock}

Next, this paper considers a tightening monetary policy in Iran. Two monetary policies are considered: interest rate and reserve requirement. The role of the banking sector in the transmission of the monetary policy shock has been investigated by previous works such as Christiano et al. (2007), Goodfriend and McCallum (2007) and Gerali et al. (2010). As discussed in Christiano et al. (2007) and Goodfriend and McCallum (2007), Financial frictions enhance the amplitude of business cycles through three channels (borrowing constraint, financial accelerator and nominal debt) besides the traditional interest rate channel. With the existence of banks, the banking attenuator effect identified by Goodfriend and McCallum (2007) and Gerali et al. (2010) is another channel to propagate business cycles. This paper also expects that the banking attenuator effect refers to a sluggish and heterogeneous pass-through of the change the interest rate to monopolistically competitive banks. Here we are not going to highlight how each channel affects the transmission of monetary policy shock, but we focus on the role of the banking sector. 
Central bank decreases interest rate. This policy has two effects on banks. First, because of the decreasing loan interest rate, interest revenue decreases and banks decrease deposit rate which leads to decrease of deposits. Households increase consumption and decrease savings. The fall at deposit leads to a further decrease in credit. As a result, investment and output decrease. Cost of production increases and it leads to decrease of inflation. Second, because of decreasing deposit, banks receive loan from interbank; then because of increasing at interbank loan, interest rate of interbank increases, then due to banking system decreases.

\section{Figure 7: Interest rate shock}
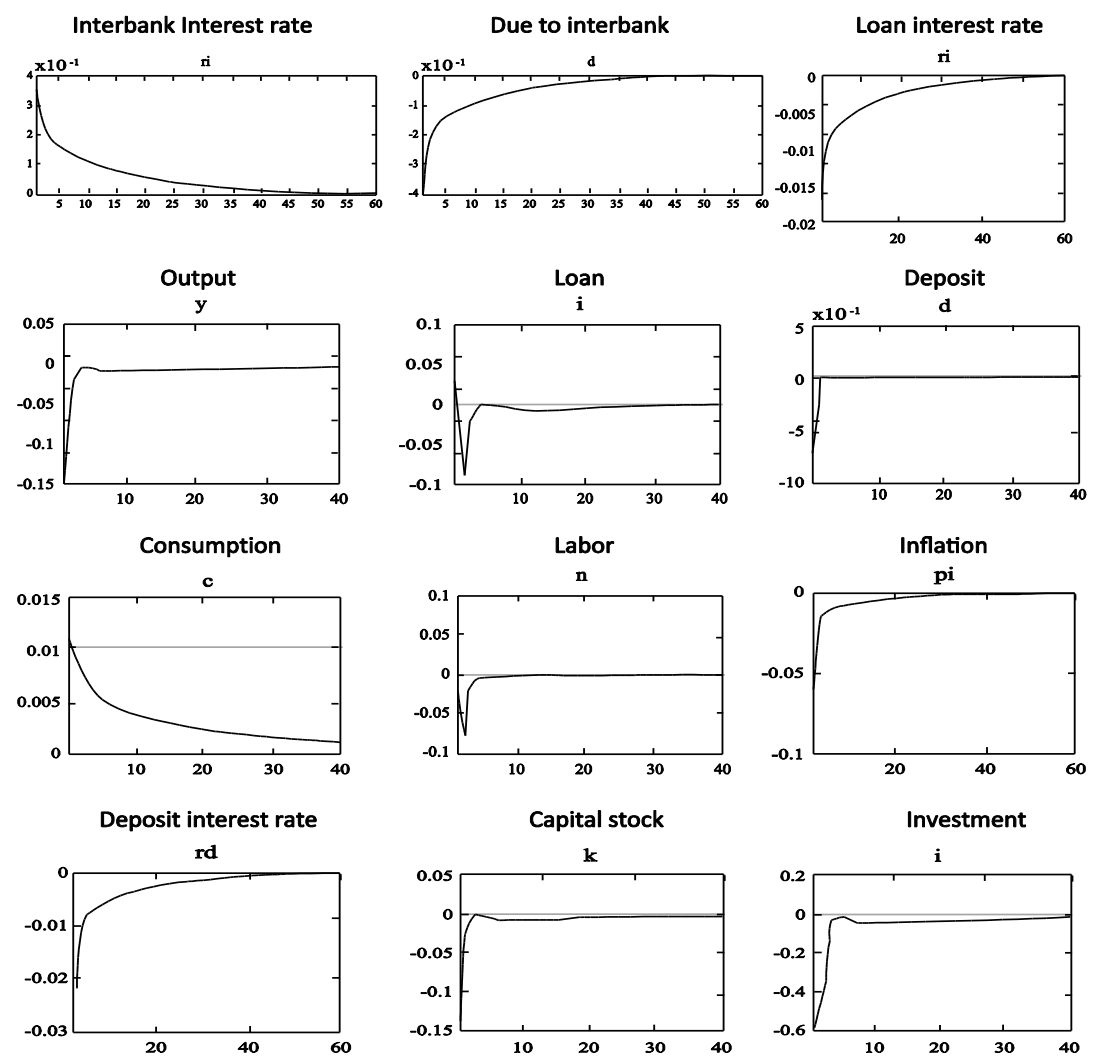
Central bank raises reserve requirement. Raising in reserve requirement usually aims at short term cash management, affects banking and leads to a further increase of bank's reserve with the central bank and interbank interest rate. Increase of interbank interest rate leads to the decrease of due to interbank. On the other hand, rise of reserve requirement leads to fall of deposit in bank and decreases operational costs. Then loan declines in response to drop of deposit and also profit of bank declines. As a result, financing, investment and output fall; but inflation rises in response to the drop in output (See figure 7).

\section{Figure 8: Reserve requirement shocks}
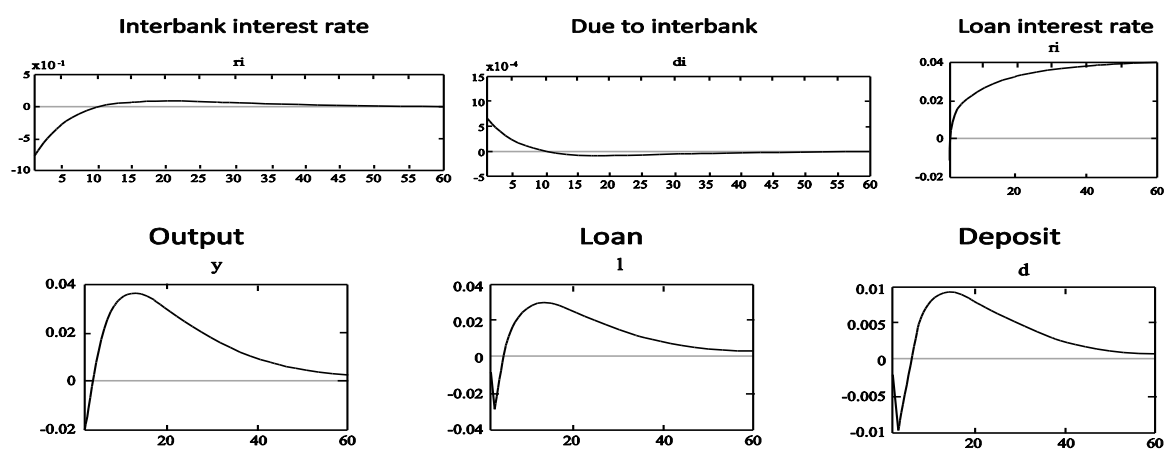

Deposit

Consumption

Labor

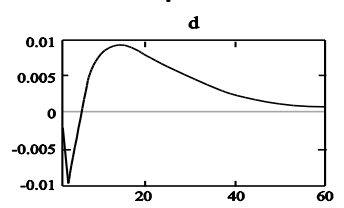

Inflation
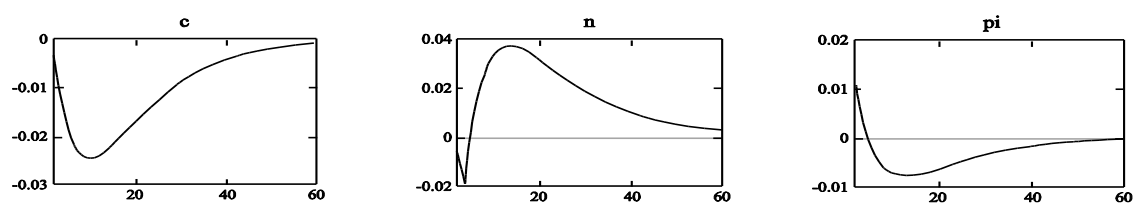

Deposit interest rate
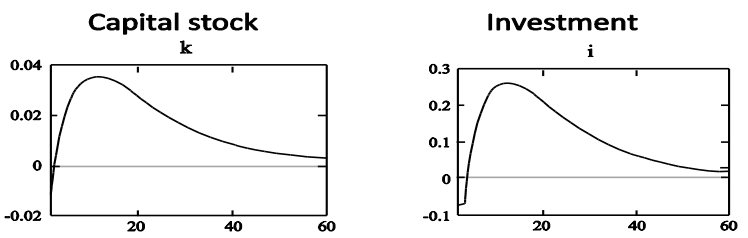


\subsection{Technology Shock}

Figure 9 shows the impacts of positive technology shock on the economy of Iran. Since the production is more efficient, output rises. The Supply of goods increases, thus reducing the price of the goods. The technology

\section{Figure 9: Technology shock}
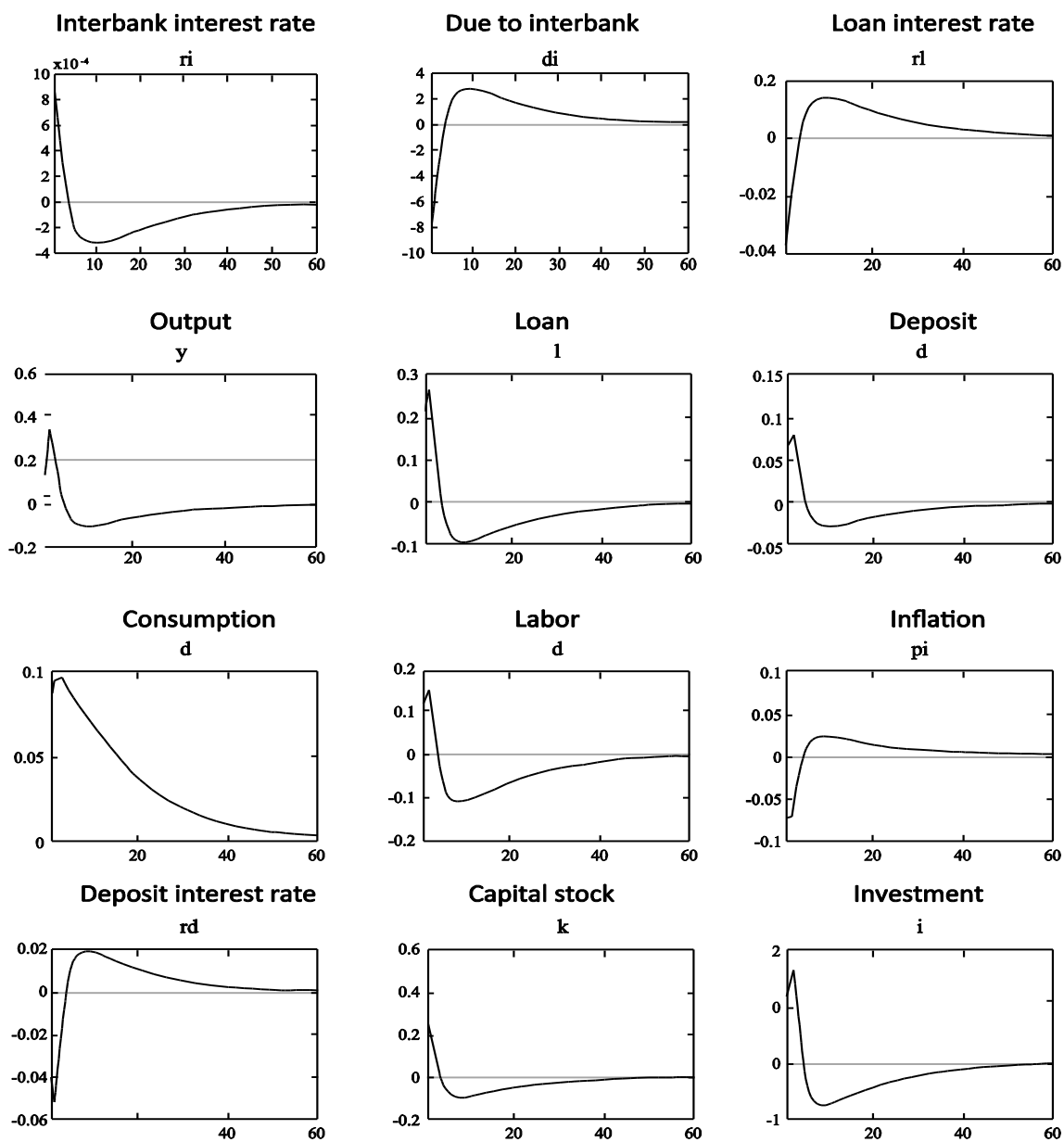
innovation reduces marginal costs and inflation, which leads to a drop in loan rate. Households raise their savings and entrepreneurs borrow more. Because of the rising savings, the marginal product of labor increases so that the aggregate capital increases. The rising in consumption leads to a rising demand for goods, therefore raising inflation. Central bank raises the loan rate. In the presence of bank intermediaries, the endogenous propagation mechanism is amplified because credit spreads benefit entrepreneurs from the greater availability of credit. Entrepreneurs borrow more and produce more. Because of raising production, inflation decreases.

\section{Concluding Remarks}

This paper proposes a micro funded framework that incorporates a banking sector into a DSGE model to evaluate the role of an active banking sector in business cycles and the contribution of financial shocks to the Iranian economy fluctuations.

Financial frictions are modeled using both the demand and supply sides of credit market. We use the financial accelerator a la $\mathrm{BGG}^{1}$ to model the demand-side of credit market. The supply-side of credit market consists of heterogeneous banks that offer different banking services and borrow from interbank market. This model provides a rich and rigorous framework to address monetary and financial stability issues. The model includes demand and supply-sides of credit market and thus allows for policy simulation analysis of factors such as: (1) credit default; (2) endogenous bank defaults on interbank borrowing; (3) monetary policies shocks.

The model reproduces salient features of the economy of Iran, reproducing volatilities of key macroeconomic variables and their correlations with output, and the pro-cyclical banks' balance sheet. Banks can affect credit supply conditions and the transmission of real effects of shocks to the economy. Also, financial shocks explain a large fraction of

\footnotetext{
${ }^{1}$ Bernanke, Gertler and Gilchrist method (1999)
} 
business cycles. This result is robust to simulations with different shocks. Thus, the main role banks play in this economy is to reduce the effects of uncertainty.

Future work will consist of estimating the model's structural parameters, incorporating credit to households, extending the framework to an open economy model and capital requirement regulations. 


\section{References}

Acharya, V. V. \& S. Viswanathan, (2008). "Moral hazard, collateral and liquidity." CEPR Discussion Papers 6630, C.E.P.R. Discussion Papers.

Bernanke, B., M. Gertler, and S. Gilchrist, (1999). The Financial Accelerator in a Quantitative Business Cycle Framework. Handbook of Macroeconomics. Amesterdam: North Holland.

Bester, H. (1987). "The role of collateral in credit markets with imperfect information". European Economic Review 31(4), 887- 899.

De Walque, Gregory de; Prirard, Olivier \& Rouabah, Abdelaziz, (2010). "Financial (in) stability, supervision and liquidity injections: a dynamoc general equlibrium approach". The economic Journal, 120, 1234-1261.

Dib, A. (2010). "Banks, Credit Market Frictions, and Business Cycle". Working paper, 2010-24: Bank of Canada.

Freixas, X. \& J. Jorge, (2008). "The role of interbank markets in monetary policy: A model with rationing", Journal of Money, Credit and Banking 40(6), 1151-1176.

Giri, F. (2014). "Does interbank market matter for business cycle fluctuation? An estimated DSGE model with financial frictions for the euro area." Univerita politecnica delte marche. Dipartimento di Scienze Economiche e Sociali, Quaderni di ricerca No. 398.

Heider, F., M. Hoerova, \& C. Holthausen, (2009). "Liquidity hoarding and interbank market spreads: The role of counterparty risk", Working paper, European Central Bank.

Iacoviello M. (2005). "House Prices, Borrwing Constraints, and Monetary Policy in the Business Cycle." American Economic Review 95: 739-64. 
Iacoviello, M. and S. Neri, (2011). "Housing Market Spillover: evidence from an estimated DSGE model". American Economic Journal: Macroeconomics, 2(2), 64-125.

Smets, Frank, and Raf Wouters. (2003). "An Estimated Dynamic Stochastic General Equilibrium Model of Euro Area". Journal of European economic Association, Vol. 1, Issue 5, pp. 1123-1175.

Weltewitz, F. (2009). "A model of credit risk in interbank Markets with Interest rate spreads". Thesis, University of Queensland. 


\section{Appendix A}

Table 4: Moments

\begin{tabular}{|c|c|c|c|c|c|}
\hline \multirow{2}{*}{ definition } & \multirow{2}{*}{ variable } & \multicolumn{2}{|c|}{ mean } & \multicolumn{2}{|c|}{ Standard deviation } \\
\hline & & real & model & real & model \\
\hline real consumption & $c_{t}$ & 0.041 & 0.04 & 0.48 & 0.44 \\
\hline supply of labor & $N_{t}$ & 0.054 & -0.053 & 0.65 & 0.61 \\
\hline $\begin{array}{l}\text { liquidity at } \\
\text { households }\end{array}$ & $M_{t}^{h}$ & 0.059 & 0.055 & 0.53 & 0.54 \\
\hline real wage & $w_{t}$ & 0.017 & 0.010 & 0.36 & 0.31 \\
\hline $\operatorname{tax}$ & $t_{t}$ & -0.074 & -0.070 & 1.58 & 1.50 \\
\hline $\begin{array}{l}\text { interest rate of } \\
\text { deposit }\end{array}$ & $r_{t}^{d}$ & 0.009 & 0.006 & 0.22 & 0.12 \\
\hline deposit & $D_{t}$ & -0.008 & -0.009 & 0.18 & 0.19 \\
\hline inflation & $\pi_{t}$ & 0.033 & 0.013 & 0.15 & 0.19 \\
\hline quantity of capital & $k_{t}$ & -0.041 & -0.044 & 0.65 & 0.63 \\
\hline investment & $i_{t}$ & -0.35 & -0.32 & 4.45 & 4.46 \\
\hline production & $Y_{t}$ & -0.038 & -0.033 & 0.78 & 0.72 \\
\hline price & $P_{t}$ & 0.015 & 0.013 & 0.21 & 0.19 \\
\hline technology shock & $A_{t}$ & 0.018 & 0.012 & 0.44 & 0.24 \\
\hline loan & $l_{t}$ & -0.036 & -0.031 & 0.73 & 0.72 \\
\hline $\begin{array}{l}\text { proportion of } \\
\text { financing }\end{array}$ & $\gamma_{t}$ & 0.0022 & 0.0025 & 0.026 & 0.024 \\
\hline marginal cost & $m c_{t}$ & 0.0041 & 0.0048 & 0.11 & 0.012 \\
\hline interest rate of loan & $r_{t}^{l}$ & 0.016 & 0.013 & 0.16 & 0.11 \\
\hline $\begin{array}{l}\text { interest rate of } \\
\text { interbanking }\end{array}$ & $r_{t}^{i}$ & -0.47 & -0.48 & 3.9 & 3.1 \\
\hline non-repayment ratio & $\gamma_{t}^{i}$ & -0.00047 & -0.00042 & 0.024 & 0.022 \\
\hline $\begin{array}{l}\text { borrowing from } \\
\text { interbank }\end{array}$ & $d_{t}^{i}$ & 0.0047 & 0.0041 & 0.028 & 0.026 \\
\hline
\end{tabular}


A Model of Financial Shocks ...

\begin{tabular}{|l|l|l|l|l|r|}
\hline \multirow{2}{*}{\multicolumn{1}{|c|}{ definition }} & \multirow{2}{*}{ variable } & \multicolumn{2}{c|}{ mean } & \multicolumn{2}{c|}{ Standard deviation } \\
\cline { 3 - 6 } & & \multicolumn{1}{c|}{ real } & \multicolumn{1}{c|}{ model } & \multicolumn{1}{c|}{ real } & model \\
\hline reserve requirement & $\eta_{t}$ & 0.031 & 0.023 & 0.16 & 0.17 \\
\hline $\begin{array}{l}\text { growth rate of } \\
\text { money }\end{array}$ & $\mu_{t}$ & 0.014 & 0.013 & 0.18 & 0.19 \\
\hline money & $M_{t}$ & 0.00017 & 0.000159 & 0.0076 & 0.0089 \\
\hline tax & $t_{t}$ & -0.075 & -0.0704 & 1.51 & 1.50 \\
\hline oil revenue & $o r_{t}$ & 0.015 & 0.014 & 0.30 & 0.34 \\
\hline $\begin{array}{l}\text { government } \\
\text { expenditure }\end{array}$ & $g_{t}$ & 0.043 & 0.049 & 0.72 & 0.73 \\
\hline
\end{tabular}

Table 5: Auto correlation, real and simulated

\begin{tabular}{|c|c|c|c|c|c|}
\hline \multirow{2}{*}{ definition } & \multirow{2}{*}{ variable } & \multicolumn{2}{|c|}{ Real auto correlation } & \multicolumn{2}{c|}{ Simulated autocorrelation } \\
\cline { 3 - 6 } & & Second lag & First lag & Second lag & First lag \\
\hline real consumption & $c_{t}$ & 0.98 & 097 & 0.97 & 0.94 \\
\hline supply of labor & $N_{t}$ & 0.82 & 0.93 & 0.61 & 0.66 \\
\hline $\begin{array}{c}0.61 \text { liquidity at } \\
\text { households }\end{array}$ & $M_{t}^{h}$ & 0.95 & 0.93 & 0.89 & 0.85 \\
\hline real wage & $w_{t}$ & 0.84 & 0.80 & 0.58 & 0.53 \\
\hline tax & $t_{t}$ & 0.83 & 0.87 & 0.61 & 0.65 \\
\hline $\begin{array}{c}\text { interest rate of } \\
\text { deposit }\end{array}$ & $r_{t}^{d}$ & 0.72 & 0.84 & 0.52 & 0.68 \\
\hline deposit & $D_{t}$ & 0.88 & 0.85 & 0.62 & 0.66 \\
\hline inflation & $\pi_{t}$ & 0.73 & 0.70 & 0.59 & 0.52 \\
\hline $\begin{array}{c}\text { quantity of } \\
\text { capital }\end{array}$ & $k_{t}$ & 0.76 & 0.85 & 0.78 & 0.70 \\
\hline investment & $i_{t}$ & 0.97 & 0.91 & 0.70 & 0.79 \\
\hline production & $Y_{t}$ & 0.85 & 0.87 & 0.61 & 0.65 \\
\hline price & $P_{t}$ & 0.73 & 0.70 & 0.59 & 0.52 \\
\hline
\end{tabular}


Money and Economy, Vol. 8, No. 4, Fall 2013

\begin{tabular}{|c|c|c|c|c|c|}
\hline \multirow{2}{*}{ definition } & \multirow{2}{*}{ variable } & \multicolumn{2}{|c|}{ Real auto correlation } & \multicolumn{2}{c|}{ Simulated autocorrelation } \\
\cline { 2 - 6 } & Second lag & First lag & Second lag & First lag \\
\hline technology shock & $A_{t}$ & 0.59 & 0.58 & 0.43 & 0.32 \\
\hline loan & $l_{t}$ & 0.87 & 0.85 & 0.61 & 0.66 \\
\hline $\begin{array}{c}\text { proportion of } \\
\text { financing }\end{array}$ & $\gamma_{t}$ & 0.81 & 0.63 & 0.45 & 0.40 \\
\hline $\begin{array}{c}\text { marginal cost } \\
\text { interest rate of } \\
\text { loan }\end{array}$ & $m c_{t}$ & 0.39 & 0.33 & 0.19 & 0.18 \\
\hline $\begin{array}{c}\text { interest rate of } \\
\text { interbanking }\end{array}$ & $r_{t}^{l}$ & 0.81 & 0.85 & 0.71 & 0.70 \\
\hline $\begin{array}{c}\text { non-repayment } \\
\text { ratio }\end{array}$ & $\gamma_{t}^{i}$ & 0.65 & 0.63 & 0.88 & 0.81 \\
\hline $\begin{array}{c}\text { borrowing from } \\
\text { interbank }\end{array}$ & $d_{t}^{i}$ & 0.68 & 0.64 & 0.48 & 0.41 \\
\hline $\begin{array}{c}\text { reserve } \\
\text { requirement }\end{array}$ & $\eta_{t}$ & 0.86 & 0.85 & 0.74 & 0.72 \\
\hline $\begin{array}{c}\text { growth rate of } \\
\text { money }\end{array}$ & $\mu_{t}$ & 0.78 & 0.69 & 0.69 & 0.53 \\
\hline $\begin{array}{c}\text { money } \\
\text { tax }\end{array}$ & $M_{t}$ & 0.81 & 0.79 & 0.58 & 0.50 \\
\hline $\begin{array}{c}\text { oil revenue } \\
\text { governmenditure }\end{array}$ & $g_{t}$ & 0.85 & 0.87 & 0.61 & 0.65 \\
\hline
\end{tabular}




\section{Appendix B: First order condition}

\section{Household}

$$
\begin{aligned}
& \frac{\partial \ell}{\partial c_{t}}=\beta^{t}\left(c_{t}\right)^{-\sigma_{c}}-\beta^{t} \lambda_{t}=0 \\
& \frac{\partial \ell}{\partial N_{t}}=-\beta^{t} N_{t}^{\sigma_{n}}+\beta^{t} \lambda_{t} w_{t}=0 \\
& \frac{\partial \ell}{\partial d_{t}}=E_{t}\left\{-\beta^{t} \lambda_{t}+\beta^{t+1}\left(\frac{1+r_{t}^{d}}{\pi_{t+1}}\right) \lambda_{t+1}\right\}=0 \\
& \frac{\partial \ell}{\partial m^{h}{ }_{t}}=E_{t}\left\{\beta^{t}\left(m^{h}{ }_{t}\right)^{-\vartheta}-\beta^{t} \lambda_{t}+\beta^{t+1} \frac{\lambda_{t+1}}{\pi_{t+1}}\right\}=0 \\
& \frac{\partial \ell}{\partial k_{t}}=-\lambda_{t}\left[1+\varphi_{k}\left(\frac{k_{t+1}}{k_{t}}-1\right)\right]+\beta\left\{\lambda_{t+1}\left[r_{t+1}^{k}+1-\delta-\frac{\varphi_{k}}{2}\left(\frac{k_{t+2}^{2}-k_{t+1}^{2}}{k_{t+1}^{2}}\right)\right]\right\}=0
\end{aligned}
$$

\section{Entrepreneur}

$$
\begin{aligned}
& \frac{\partial \ell}{\partial k_{t}}=\lambda_{t} A_{t} \alpha N_{j t}^{1-\alpha} K_{j t}^{\alpha-1}-\lambda_{t}^{f} r_{t}^{k}\left(1+r_{t}^{l}\right)=0 \\
& \frac{\partial \ell}{\partial N_{t}}=\lambda_{t} A_{t}(1-\alpha) N_{j t}^{-\alpha} K_{j t}^{\alpha}-\lambda_{t}^{f}\left(1+r_{t}^{l}\right) w_{t}=0
\end{aligned}
$$




$$
\begin{aligned}
& \frac{\partial \ell}{\partial P_{t}}=\left\{1-\theta+\theta\left(\frac{P_{t}}{P_{j t}}\right) m c_{j t}\right\} \lambda_{t}\left(\frac{P_{j t}}{P_{t}}\right)^{-\theta} \frac{Y_{t}}{P_{t}}-\lambda_{t} \varphi_{f}\left\{\left(\frac{P_{j t}}{(\bar{\pi}) P_{j t-1}}-1\right) \frac{Y_{t}}{(\bar{\pi}) P_{j t-1}}\right\} \\
& +\beta \varphi_{f} E_{t}\left\{\lambda_{t+1}\left(\frac{P_{j t+1}}{(\bar{\pi}) P_{j t}}-1\right) Y_{t+1}\left(\frac{P_{j t+1}}{(\bar{\pi}) P_{j t}^{2}}\right)\right\}=0
\end{aligned}
$$

$$
m c_{j t}=\frac{\left[\gamma_{t}\left(1+r_{t}^{l}\right) w_{t}\right]^{1-\alpha}\left(\gamma_{t}\left(1+r_{t}^{l}\right) r_{t}^{k}\right)^{\alpha}}{\alpha^{\alpha}(1-\alpha)^{1-\alpha} A_{t}}
$$

\section{Commercial bank}

$$
\begin{aligned}
& \frac{\partial \ell}{\partial l_{t}}=\lambda_{t} \alpha^{b}\left(1+r_{t}^{l}\right)-\lambda_{t}^{b}=0 \\
& \frac{\partial \ell}{\partial d_{t}}=-\lambda_{t}\left(1+r_{t}^{d}\right)+\left(1-\eta_{t}\right) \lambda_{t}^{b}=0 \\
& \frac{\partial \ell}{\partial d_{t}^{i}}=-\lambda_{t}\left(\left(1+r_{t}^{i}\right)+\varphi_{d i}\left[\frac{D_{t}^{i}}{\bar{D}^{i}}-1\right]+\varphi_{d i \gamma}\left[\left(\gamma_{t}^{i}\right)^{2} D_{t}^{i}\right]\right)+\lambda_{t}^{b}=0 \\
& \frac{\partial \partial}{\partial \gamma_{t}^{i}}=-\left(1+r_{t}^{i}\right) D_{t}^{i}-\varphi_{d i \gamma}\left[\left(\gamma_{t}^{i}\right)\left(D_{t}^{i}\right)^{2}\right]=0
\end{aligned}
$$

Appendix c: Log linear of the model

$$
\tilde{w}_{t}=\sigma_{c} \tilde{c}_{t}+\sigma_{n} \tilde{N}_{t}
$$




$$
\begin{aligned}
& \tilde{c}_{t}=\frac{\tilde{\pi}_{t+1}-\tilde{r}_{t}^{d}}{\sigma_{c}}+\tilde{c}_{t+1} \\
& \tilde{m}_{t}^{c}=\frac{1}{\vartheta}\left(-\tilde{r}_{t}^{d}+\sigma_{c} \tilde{c}_{t}\right) \\
& \tilde{r}_{t+1}^{k}=\frac{\sigma_{c}}{1-\beta(1-\delta)}\left(\tilde{c_{t+1}}-\tilde{c_{t}}\right) \\
& \tilde{k}_{t+1}=(1-\delta) \tilde{k_{t}}+\delta \tilde{i}_{t} \\
& \tilde{N}_{t}=\tilde{k_{t}}-\tilde{w_{t}}+\tilde{r}_{t}^{k} \\
& \tilde{\pi}_{t}=\left(\frac{\theta-1}{\varphi_{f}}\right) m \tilde{c}_{t}+\beta \tilde{\pi}_{t+1}
\end{aligned}
$$

$m \tilde{c_{t}}=(1-\alpha)\left(\tilde{w_{t}}\right)+\alpha \tilde{r}_{t}^{k}+\tilde{r}_{t}^{l}-\tilde{A}_{t}+\tilde{\gamma}_{t}$

$\tilde{y}_{t}=\tilde{A}_{t}+(1-\alpha) \tilde{N}_{t}+\alpha \tilde{k_{t}}$

$\tilde{l_{t}}=\bar{\gamma}\left(\left(\tilde{r}^{k}+\tilde{k}_{t}\right) \frac{\bar{r}^{k} \bar{k}}{\bar{l}}+\frac{\bar{w}}{\bar{l}} \tilde{w}_{t}\right)+\tilde{\gamma}_{t}$

$\tilde{d}_{t}=\frac{\bar{l}}{(1-\bar{\eta}) \bar{d}} \tilde{l}_{t}-\frac{\bar{d}^{i}}{(1-\bar{\eta}) \bar{d}} \tilde{d}_{t}^{i}+\frac{\bar{\eta}}{(1-\bar{\eta})} \tilde{\eta}_{t}$

$\tilde{r}_{t}^{d}=\frac{\alpha_{t}^{b} \bar{r}^{l}(1-\bar{\eta})}{\bar{r}^{d}} \tilde{r}_{t}^{l}-\frac{\bar{\eta}\left(1+\bar{r}^{l}\right)}{\alpha^{b} \bar{r}^{l}(1-\bar{\eta})} \tilde{\eta}_{t}+\alpha_{t}^{b}$

$\tilde{d}_{t}^{i}=\phi_{d i}^{d i} \tilde{d}_{t-1}^{i}+\phi_{d i}^{y} y_{t}$ 
$\tilde{\gamma}_{t}^{i}=\rho_{\gamma^{i}} \tilde{\gamma}_{t-1}^{i}+\varepsilon_{t}^{\gamma^{i}}$

C-14

$\tilde{r}_{t}^{i}=\frac{\alpha_{t}^{b} \bar{r}^{l}}{\bar{r}^{i}} \tilde{r}_{t}^{l}-\frac{\phi d i \gamma+\varphi d i}{\bar{r}^{i}}\left(\tilde{d}_{t}^{i}-2 \tilde{\gamma}_{t}^{i}\right)$

$\tilde{\dot{m}}_{t}=\tilde{m}_{t}-\tilde{m}_{t-1}+\tilde{\pi}$

$\tilde{r}_{t}^{l}=\rho_{r} \tilde{r}_{t-1}^{l}+\rho_{\pi} \pi_{t}+\rho_{y} y_{t}+\rho_{m} \mu_{t}+\varepsilon_{r_{t}^{d}}$

$\tilde{\eta}_{t}=\phi_{\eta}^{\pi} \tilde{\pi}_{t}+\phi_{\eta}^{\eta} \tilde{\eta}_{t-1}+\varepsilon_{t, \eta}$

$\tilde{g}_{t}=\frac{\bar{t}}{\bar{g}} \tilde{t}_{t}+\frac{o \bar{r}}{\bar{g}} o \tilde{r}_{t}+\frac{\bar{m}}{\bar{g}}\left(\tilde{m}_{t}-\tilde{m}_{t-1}+\tilde{\pi}_{t}\right)$

$\tilde{t_{t}}=\phi_{t}^{y} \tilde{Y}_{t}$

$\tilde{y}_{t}=\frac{\bar{c}}{\bar{y}} \tilde{c}_{t}+\frac{\bar{i}}{\bar{y}} \tilde{i}_{t}+\frac{\bar{g}}{\bar{y}} \tilde{g}_{t}$

$\tilde{m}_{t}=\frac{\bar{m}^{h}}{\bar{m}} \tilde{m}_{t}^{h}+\frac{\bar{d}}{\bar{m}} \tilde{d}_{t}$

$\tilde{\gamma}_{t}=\rho_{\gamma} \tilde{\gamma}_{t-1}+\varepsilon_{t}^{\gamma}$

$\tilde{A}_{t}=\rho_{A} \tilde{A}_{t-1}+\xi_{t}^{A}$

$o \tilde{r}_{t}=\rho_{o r} o \tilde{r}_{t-1}+\varepsilon_{o r}$ 